Çukurova Üniversitesi Mühendislik Mimarlık Fakültesi Dergisi, 32(1), ss. 165-176, Mart 2017

Çukurova University Journal of the Faculty of Engineering and Architecture, 32(1), pp.165-176, March 2017

\title{
Mekansal Komşuluk Kavramı Üzerinden Mimari Mekanın Analizi
}

\author{
Onur ERMAN ${ }^{* 1}$ \\ ${ }^{1}$ Çukurova Üniversitesi, Mühendislik Mimarlık Fakültesi, Mimarlık Bölümü, Adana
}

Geliş tarihi: 09.01.2017～Kabul tarihi: 14.03 .2017

$\ddot{\mathbf{O} z}$

Mekan konfigürasyonunun analizine odaklanan bu çalışma, "mekansal komşuluk" kavramını öne sürerek bu kavram ışığında mekansal ilişkileri irdelemektedir. Çalışma bu kapsamda mimari kurguda komşuluk eden mekanların bütün içindeki ilişkisel rolünü sorgulamayı ve farklı mekansal komşuluk şekillerinin mekan kurgusuna ve anlamına etkisini tartışmayı hedeflemektedir. Çalışmanın araştırma yöntemi Mekan Dizilimi Analizlerine dayanmakta ve örneklem grubunu farklı dönemlere ait müstakil konut örnekleri oluşturmaktadır. Dizilim analizleri kapsamında derinlik ve entegrasyon değerlerine bakılarak, geçiş modeli analizleri yapılmıştır. Ulaşılan dizilim değerleri yardımıyla farklılaşan mekansal komşuluk ilişkileri tespit edilerek, mekan kurgusuna ve mekanın anlamına etkisi tartışılmıştır. Sonuçlar mekan konfigürasyonu içinde mekansal komşuluk ilişkilerinin değişiminin mekanın kullanımı, anlamı ve bütün içindeki konumuna nasıl etki ettiğini göstermektedir.

Anahtar Kelimeler: Mekansal komşuluk, Mekan konfigürasyonu, Mekansal ilişkiler, Mekan dizilimi analizi, Konut

\section{Analysis of the Architectural Space through the Spatial Neighbourhood Concept}

\begin{abstract}
This study, which focuses on the analysis of spatial configurations, examines the concept of "spatial neighbourhood". It aims at questioning the relational role of the neighbouring spaces within a whole as well as discussing the effects of different forms of spatial neighbourhood on the layout and meaning of spaces. The method of the study is based on Space Syntax Analysis and the sample group of the analysis consists of single family houses from different periods. For the syntactic analysis, mean depth, integration and justified graph analysis are realized. Using the syntactic values obtained, changes in spatial relations are revealed and the effects of these changes on the structure of spatial neighbourhood and to the meaning of space are discussed. The results of the study reveal the effects of the changings in spatial neighbouring relations in the spatial configuration in the use, the meaning and the position of space within a whole.
\end{abstract}

Keywords: Spatial neighbourhood, Spatial configuration, Spatial relations, Space syntax analysis, House

*Sorumlu yazar (Corresponding author): Onur ERMAN, oerman@cu.edu.tr 


\section{GíRiș}

İnsan ile çevre arasında kurulan ilişki mekansaldır. Birey ihtiyaçlarını karşılamak için davranıs ya da davranış dizilerini gerçekleştirir ve böylece ihtiyaçlar ve karşllığ olan davranışlar mekansallaşır. Markus [1] mekan ve davranış ilişkisini "her ne yapılırsa yapılsın mutlaka bir yerde yapılır" şeklinde ifade eder. Bu ifade bir yandan mekanın inşa nedenini açıkça ortaya koyarken, diğer yandan davranışın geçmediği bir mekandan söz etmenin mümkün olamayacağını vurgular. Ancak mekanın varlığı diğer mekanlarla kurduğu ilişkilere dayanır. Herhangi bir başka mekanla ilişkisi olmayan bir mekan kullanılamaz, dolayısıyla var olamaz.

İlişkilerin organize edildiği ve davranışsal alanların tanımlandığı mimari tasarımda; mekanlar ve mekansal ilişkiler soyut bir biçimde geometrik olarak ifade edilir. Mekanı tanımlayan her bir çizgi diğerleri ile sonsuz alternatifle bir araya gelebilir ve sonuçta çizgilerin kesişmesi, kopması, birleşmesiyle işlevsel bir alan tanımlanır. Mimari tasarım; mekana ait boyutsal, biçimsel özelliklerle birlikte, bütüne dahil olan mekanları ve onların ilişkili olduğu diğer mekanları, bu mekanlara nasıl ulaşılacağı ve nasıl kullanılacağı gibi bilgileri basit ve açıkça ifade eder. Ancak bunun ötesinde, mekanın sosyal ve kültürel bir olgu olmasının bir sonucu olarak ortaya çıkan, daha karmaşık yapıda ve kolayca anlaşılamayacak şekilde sosyokültürel ve sosyopsikolojik düzeyde beliren mekansal ilişkileri, mekanın sunduğu yaşantıyı, değișen koşullarda mekanda kimlerin bulunacağı ya da kimlerin hariç tutulacağı gibi bilgilerin yanı sıra, mekanın kullanıcısında çeşitli anlamlar oluşturabilecek ve farklı psikolojik etkiler yaratabilecek bilgileri de içerir. Bu bakımdan mekan semantik bir olgudur ve anlam iletir. Mekana ait anlam belli kurallarla şifrelenerek kodlanır ve mekanın algılanabilir özellikleriyle kullanıcıya ulaşır. Kodlar ve anlamlar konusunda yaşama ait en açık ve kolay anlaşılır örneklerden biri dildir. Kelimeler birer ses topluluklarıdır ve kelimeleri bir araya getiren dil kurallarıdır. Cümlede kelimelerin diziliş sırası kurallarla belirlenir ve sıralanma șekli cümlenin anlamını etkiler. Bir yapı bütünü içinde mekanların bir araya gelmesi cümle içinde kelimelerin bir araya gelmesine benzetilebilir. Cümlenin anlamlandırılması için seslendirilmesi gerekliyken mekansal kurgunun anlamlandırılması için mekansal ilişki düzenin kavranması gerekir. Kavrama ancak bütünün içinde ilişkili mekanlar arasında dolaşarak oluşur. Hillier vd. [2] mekansal ilişkinin olması için boşluğun gerekli olduğunu söyler. Boşluk sınırdaş iki mekan arasındaki geçişi sağlar ve bağlantıyı kurar. Boşluğun oluşumu ve ilişkilerin düzeni ise sınırların niteliği ile ilgilidir. Sınırlar mekanı fiziki olarak tanımlar ve içeridekileri dışarıdakilerden hariç tutar ya da bir grubu diğerlerinden ayırarak fiziki ve sosyal olarak birlikteliğini sağlar. Dolu yüzeyler sınırları kesin olarak belirler ve ayırır, şeffaf yüzeyler kontrollü bir ilişki sağlar, boşluklar ve boşluklu yüzeyler ise fiziki olarak dahil olmayı sağlayarak sosyal ilişkileri temasla destekler. Mekanın bir diğer mekan arasında ilişkinin-geçişin olması ve geçişin niteliği bir yandan mekanları organize ederken bir yandan da kullanıcılar arasındaki ilişkiyi karakterize eder. Bunlara ek olarak mekan nesnel özelliklere sahip olsa da bir nesne olarak tanımlanmaktan çok bir örüntü olduğu söylenebilir. Bu örüntüde 1şık, ses, renk, doku gibi nesnel unsurlar bir araya gelirken, aynı zamanda mekanı yaratan organizma subjektif biçimde mekansallaşır, mekandaki varlı̆̆ını ifade eden ilişki örüntüleri kurgulanır [3]. Bu bakımdan mekan kurgusu işlevsel organizasyondan çok ilişskiler organizasyonudur ve sosyal ilişkiler ve süreçler kendilerini mekan ve mekansal ilişkilerle ifade eder [2].

$\mathrm{Bu}$ ifadelere göre mekan kurgusu içinde ilişkili yakınlığın ilişkisiz sınırdaşlıktan daha anlamlı olduğu düşünülmektedir. Konfigürasyonel açıdan mekansal komşuluk kavramı kurgu içinde mekansal geçişlerle mekanların birbirine bağlanması olarak yorumlanabilir. Bu nedenle mekansal komşuluk için geometrik yakınlığın önemli olmadığ bağlantı sayısı ile ilgili olduğu düşünülebilir. Dolayısıyla mekansal komşuluk kavramında kurgusal ilişkinin doğal olarak geometrik değil topolojik olduğu söylenebilir [4]. Bu ilişkinin çözümlenmesi yapı yüzüne bakarak değil, ancak 
bina içine girdikten sonra dolaşarak edinilen deneyimle sağlanır [1].

Mekansal komşuluk kavramı Şekil 1'de yer alan A ve B mekanları yardımıyla açıklanmaya çalışılmıştır. Bu iki mekan şekilde görüleceği üzere sınırdaştır ve geometrik düzen içinde yan yanadır. Ancak şemalarda A ve B mekanları sınırdaş olsalar da bu iki mekanın birbirine göre mekansal komşuluk durumu değişiklik göstermektedir. Şekil 1.i'de A mekanından B'ye bir geçiş ile ulaşırken, Şekil 1.ii'de A mekanından B'ye ulaşmak için yedi adet geçiş aşmak gerekir. Şemalar karşılaştırıldığında her iki mekanın geometrik yapı içindeki yeri değişmese de topolojik uzaklıklarının değiştiği görülmektedir. $\mathrm{Bu}$ durumda, (i) örneğindeki B mekanı A mekanına topolojik olarak daha yakınken (ii) örneğindeki B mekanı topolojik olarak daha uzaktır. Bu örnek üzerinden mekansal komşuluk kavramı geometrik yakınlığın ötesinde, mekansal geçişlerle sağlanan ilişkili yakınlık olarak tanımlanabilir.
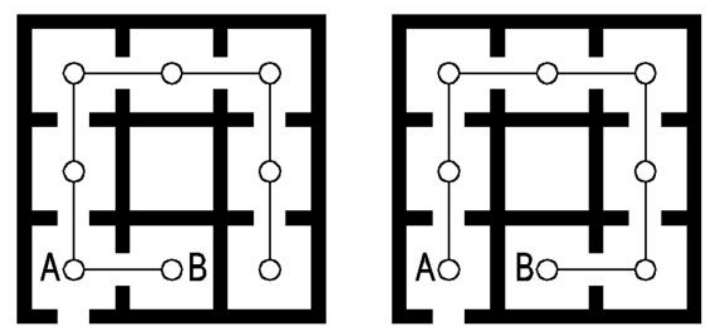

\section{(i) Yakın mekansal komşuluk ilişkisi}

konfigürasyonu olarak adlandırır. $\mathrm{Bu}$ anlamda mekan konfigürasyonu; mekanlar arasındaki geçişte sıralama-ardı ardına geliş, geçişte hareket rotasının değişimi, alternatif geçişlerin varlığı ve farklı yönlerdeki geçiş rotalarının kesişiminini kapsar.

Kurguda yer alan mekanların hangi mekanlarla bağlantılı olduğu ve bağlantılı mekanların birbirine göre önce ya da sonra oluşu ise mekan dizilimi olarak adlandırılır. Mekanın dizilim değeri kurguya ait tüm mekanlar arasındaki geçiş sıralamasında ilişkide olduğu önceki ve sonraki mekanlara göre saptanır. Dizimsel yapının analizi Hillier ve Hanson [5] tarafindan geliștirilen Mekan Dizilimi Yöntemi (Space Syntax Method) yardımiyla yapılabilmektedir. $\mathrm{Bu}$ analiz yöntemiyle kurguya ait dizimsel özelliklerin tespiti, değerlendirilmesi ve yorumlanması mümkün olur.

Çalışma, mekanın karakterinin ilişkili olduğu diğer mekanlarla tanımlandığı, mekansal kurgu içindeki yerinin mekanın anlamlandırılmasını ve kullanımını etkilediği savlarından yola çıkarak mekansal komşuluk ilişkilerinin değişimininin mekanın karakterini nasıl etkilediğini analiz etmeye çalışmaktadır. Bu kapsamda Hillier ve Hanson'un mekan dizilimi yöntemi kullanılarak ilgili analizler yardımıyla değerlendirmeler yapılması hedeflenmektedir.

\section{MEKAN DİZILIMİ YÖNTEMİ ve ANALİZLERİ}

Mekanın sınırları ile inşa edildiğinden, sınırlar ve boşluklarla ilişki örüntülerinin oluştuğundan önceki bölümde söz edilmişti. Bu örüntü sosyal ilişkileri yapılandırır ve kültür gibi yaşama ait değerler mekansal biçim yardımıyla anlaşılır hale gelir. Böylece mekan işlevsel, biçimsel ve anlamsal olarak kurgulanmış olur. Mekan dizilimi analizi "sosyal ve kültürel olarak tanımlanmış örüntüler mekan kurgusu içine gizlenmiştir" görüşünü temel alarak mekan kurgusunun temsilini ve sayısal analizini kapsar [2]. Bu teknik, plan şemasının önerdiği sosyal işlev ve ilettiği kültürel anlamla doğrudan ilişkili olan konfigürasyonel 
özelliklere dayanarak mimari mekanı analiz eder. Mekan konfigürasyonun anlaşılması için mekanların ilişkili olmaktan doğan yakınlıklarını incelemek gerekir. Hillier'e [6] göre iki mekan arasındaki ilişki konfigürasyonu bir üçüncü mekan olmaksızın belirlenemez. Çünkü iki mekan arasındaki ilişki sadece basit bir bağlantı olurken, konfigürasyon bütüne ait ilişkileri anlamaya yarar. Şekil 2.(i)'de sadece birbiriyle ilişkili iki hücrenin değişiklik göstermeyen ve bu nedenle anlam taşımayan ilişkisi görülmektedir.

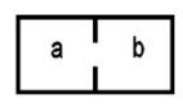

(i)
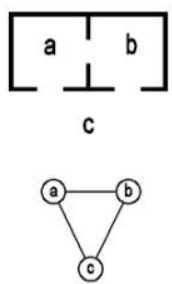

(ii)

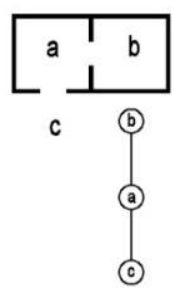

(iii)
Şekil 2. Mekan konfigürasyonunda değişim ve geçiş modelinde ifadesi [5]

Değişen mekansal ilişkiler mekan konfigürasyonunun da değişmesini sağlar. Dolayısıyla Şekil 2.(ii)'de görüldüğü gibi A ve B mekanına bir C mekanının eklenmesiyle mekansal ilişkiler değişmiş ve konfigürasyon farklılaşmıştır. $\mathrm{Bu}$ nedenle konfigürasyonun çözümlenebilmesi için ilişkili mekan çiftleri yerine bütüne ait mekansal ilişkilerin tamamının dikkate alınması gerekir. Mekansal ilişkilerin şekli ayrıca kurgunun simetrik ya da asimetrik yapıda olmasını belirler. Şekil 2.(ii)'de C'den B'ye A yoluyla gelmek ya da C'den A'ya B yoluyla gelmek aynı şekilde sonuçlanır. $\mathrm{Bu}$ iki mekanın birbiri üzerindeki kontrolü bu durumda eşittir ve bu nedenle kurgu simetriktir. Ancak Şekil 2.(iii)'de A ve B arasındaki ilişki C'ye göre asimetriktir ve mekanların kurgu içindeki değeri değişis. C'den B'ye ulaşmak ancak A hücresinden geçerek olur ve bu durumda A hücresi B'yi kontrol eder.

Mekan Dizilimi Analizi üç temel analiz yöntemini içerir [4]:

a) Mekansal Örüntünün Analizi: Binalar tasarım programında yer alan mekanların ne olduğundan çok bu mekanların nasıl ilişkilendirildiği ile oluşur. Dolayısıyla binalar mekanlar bütünü olmakla beraber aslında mekansal ilişkilerle oluşmuş örüntülerdir. Mekanlar arasındaki ilişki örüntüsü tasarımda farklılık gösterebilir. İlişki örüntüsü mekanın diğerlerine göre önce ya da sonra oluşunu tanımlarken aynı zamanda mekanın kullanım ve sosyal değerini de ifade eder. Mekansal ilişki örüntülerinin analizinde ana yöntem geçiş (graph) diyagramlarının modellenmesidir. $\mathrm{Bu}$ analizde mekan konfigürasyonunda her bir işlevsel birim bir hücre olarak ele alınır ve modelde bir daireyle, bir hücrenin diğer hücrelerle olan ilișkisi ise geçişleri belirten çizgilerle ifade edilir. Bu analizde mekanın büyüklüğü önemsizdir ve mekanların ilişkisini ifade eden çizgilerin uzunluğu, yönü ya da şekli anlam taşımaz. Geçiş analizi dizilimde seçilen bir mekana göre diğer mekanların ilişkisini ve durumunu gösterir. Dolaşımın başlangıç yeri olarak seçilen mekan geçiş modelinde kök olarak adlandırılır ve $\oplus$ işareti ile temsil edilir.

Geçiş modeli analiziyle öncelikle basit bir biçimde mekanların derinlik durumu karakterize edilir. Bir hücrenin derinliği kök mekana göre seçilen hücreye ulaşmak için sırasıyla geçilen hücre sayısına dayanarak belirlenir. Kök mekana göre " 1 " derinlik değeri mekana doğrudan ulaşıldığını, "2" derinlik değeri ise mekana ulaşmak için bir diğer mekanın geçilmesi gerektiğini ifade eder [2]. Bu bakımdan derinlik mekanlar arasındaki ilişkisel uzaklık olarak yorumlanabilir.

Topolojik yapının çözümlenmesine imkân tanıyan geçiş modeli analizinde derinliğin değişmesi konfigürasyonun biçimsel ifadesini değiştirir. Bağlantılı hücre sayısından bir eksik bağlantı sayısının olması geçiş modelinin ağaç formunda olmasını sağlar. Mekansal kontrolün yüksek ve mekan hiyerarşinin fazla olduğu kurgularda asimetrik yapıyla birlikte derinlik artar ve geçiş modeli derin ağaç formu kazanır. İlişkilerin çeşitlendiği durumlarda dallanmış ve sığ ağaç formu oluşur. Mekana halkaların dahil olmasıyla beliren alternatif rotalar simetrik yapının oluşmasını sağlar ve geçiş modelinde derinliğin azalmasına neden olur. Bunlara ek olarak kök mekanın değişmesi geçiş modelini farklılaştırır [7], (Şekil 3). 

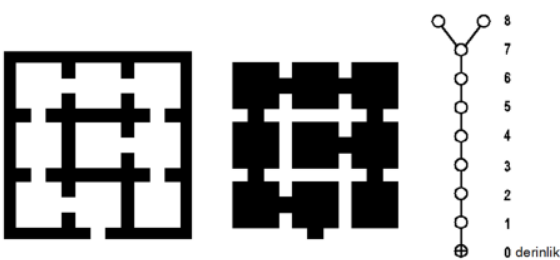

a) Derin ăgaç formlu geçiş modeli
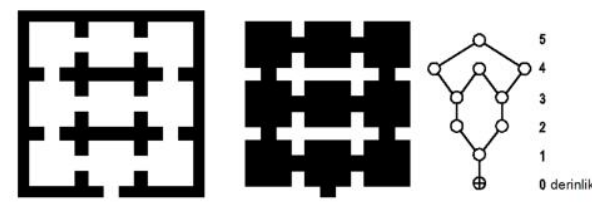

c) Sı̆̆ halkalı geçiş modeli
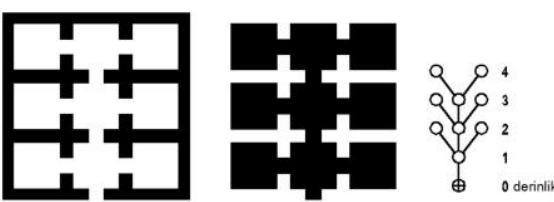

b) Siğ ă̆aç formlu geçiş modeli
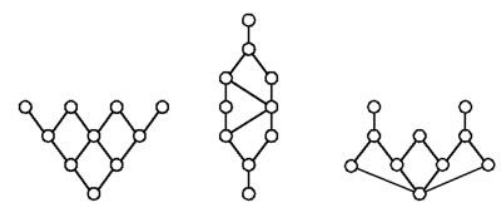

d) c şemasının farklı kök mekanlara göre değişen geçiş modelleri

Şekil 3. Farklı geçiş modeli örnekleri ve kök mekana göre geçiş modelinin değişimi [7]

Şekil 3'de aynı geometrik forma sahip ancak farklı mekansal geçişleri içeren şemaların geçiş modelleri yer almaktadır. Şemalarda geometriler aynı olsa da mekansal ilişkilerin değişmesiyle kurgunun farklılaşması ve geçiş modelinde derinliğin değişmesi açıkça görülmektedir. Görsellerde "a" derin ağaç (8 derinlik), "b" sı ğ ağaç (4 derinlik), "c" sığ halkalı (4 derinlik) geçiş modelleridir. Şekil 3.c'de halkaların dahil olmasıyla oluşan alternatif rotaların mekan derinliğini nasıl değiştirdiği (3, 6 ve 3 derinlik) ve Şekil 3.d'de aynı kurguda kök mekanın değişmesinin geçiş modelini nasıl farklılaştırdığı gözlenmektedir. b) Dışbükey (Konveks) Mekan Analizleri: Dıșbükey mekanların ilișkili komşuluk durumu analizini içerir. $\mathrm{Bu}$ analizlerde sınırların tanımladığı ilişkili boşlukları kesintiye uğramadan geçen en uzun düz çizgilerin birbiriyle ilişkisini analiz eden aksiyal harita analizi, görsel bağıntıları irdeleyen isovist harita analizi ve boşlukların derinlik ve geçiş ilişkilerine dayanan konveks harita analizi yer alır (Şekil 4).

Mekanın geometrik ilişkisine dayanarak morfolojik çözümlemesini yapabilmek için bu analizler kullanılabilir.

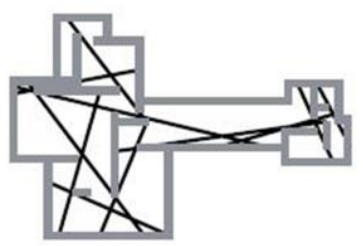

a) Aksiyal harita analizi

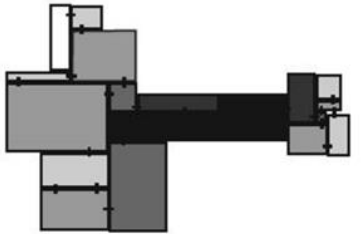

b) Konveks harita analizi

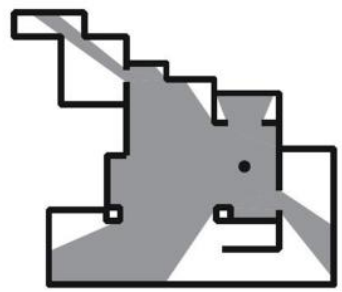

c) Isovist harita analizi

Şekil 4. Konveks mekan analizleri [8] 
c) Geçiş (Graph) Kuramsal Ölçmeler: Geçiș modellemesi yapılan konveks harita analizleri yardımıyla mekansal kurgunun entegrasyon, ortalama derinlik, toplam derinlik, adım derinliği, göreceli entegrasyon, göreceli asimetri, gerçek göreceli asimetri gibi matematiksel hesaplamalarını içerir.

Konveks harita analizinde entegrasyon en temel geçiş (graph) bazlı ölçmedir. Entegrasyon değeri geçiş modeli içinde yer alan diğer mekanlara göre mekanın göreceli derinliğidir. Bu değer seçilen bir mekandan herhangi bir diğer mekana ulaşmak için geçilen mekan sayısı ve bu mekanların sistem içindeki derinliğiyle ilişkilidir. Entegrasyon dizimsel ulaşılabilirliği ve böylece kurgu içinde mekanın merkezilik durumunu ölçer [8]. Entegrasyon değeri 0 ile 1 arasında değişir. Sıfira yakın olmak maksimum entegrasyonu, düşük derinliği ve dizimsel olarak merkeziliği vurgularken, 1'e yakın olmak daha az ulaşılabilir ve merkezden uzak olmayı işaret eder. Ortalama derinlik seçilen mekanın bütün içinde ne derece derin ya da yüzeysel olduğunu belirler. Ortalama derinlik değeri entegrasyonun dağılımı ve eşit dizimsel büyüklüğe sahip farklı sistemlerin karşılaştırılabilmesi için kullanılan göreceli asimetri değerinin hesaplanması için gereklidir. Ancak bir mekana göre sistemin ortalama derinlik değeri ve tüm mekanların averaj ortalama derinlik değeri seçilen sistemin büyüklüğüne bağlı olarak değişir [8]. Bu nedenle farklı sentaktik büyüklüğe sahip sistemlerin analizi için gerçek göreceli asimetri (RRA) değerinin bilinmesi gerekir. Göreceli asimetri değerinin tersi (1/RRA) entegrasyon değerini verir [9]. Farklı büyüklükteki sistemlerin dizilim değerlerinin karşılaştırılması bu veriler yardımıyla yapılabilir.

\section{MEKANSAL KOMSSULUK KAVRAMININ ANALIZI}

\section{1. Çalış̧anının Materyali}

Konut sosyokültürel bir olgudur ve toplumsal değerlerle biçimlenmesi nedeniyle değişime açıktır. Sosyoekonomik ve sosyokültürel değişimin konuta yansıması biçimsel olduğu kadar mekansaldır. Bu değişim farklılaşan tipleri işaret eden kurgusal yapıda kendini gösterir. Ayrıca statünün, kişiliğin, zevk ve beğenilerin ifadesi, bireyin varlığını ifade ettiği öz alanı olması [10] konutu kolay manipüle edilebilir kılar. Bu bakımdan sadece değişen mekansal ilişkilerin analiz edilebilmesi için değil pek çok farklı araştırma konusu için konut zengin bir laboratuvardır.

Çalışmada değişen mekansal ilişkilerin analizi için Adana'da farklı dönemlerde inşa edilmiş müstakil konut örnekleri uygulamaya konu edilmiştir. Örneklerin seçiminde Erman vd.'nin [11] Adana'da konut yapılarının sosyokültürel ve sosyoekonomik bağlamda değişimini inceledikleri çalışmadan yararlanılmıştır. Konutun sosyal ve kültürel bir olgu olduğunun altını çizen çalışmada Adana kentinde konutun değişimi kentte yaşanan sosyal ve ekonomik değişimlere paralel olarak dönemlere ayrılmış, her dönem için konut karakteri tasvir edilerek, yıllar içindeki değişim ortaya konulmuştur.

Anılan çalışmada yazarlar Adana'da konut gelişimini, bu bağlamda değişimini dört dönemde ele almıştır. Bu çalışma ise anılan çalışmada tespit edilen dönemleri esas alarak, konutun daha çok bireysel kararlarla inşa edildiği ve toplumsal değerlerin belirgin bir biçimde ve daha homojen olarak gözlenebildiği 1920-1930'lar, 19401950'ler ve 1960-1970'ler olmak üzere üç döneme odaklanmıştır. Bu kapsamda her dönem için seçilen üç karakteristik örnek üzerinden mekansal ilişkileri çözümlemeye yönelik analizler gerçekleştirilmiştir.

\section{2. Çalışmanın Yöntemi}

Hillier ve Hanson [5] mekan dizilimi yönteminden söz ederken sosyal değişimlerin mekansal yansımalarını analiz etmek için elverişli bir yöntem olduğunu belirtir. Bu yöntem pek çok çalışmada yapılaşmış çevreyi farklı yönleriyle ve farklı ölçeklerde analiz etmek için kullanmıştır. Bu çalışma; mekan dizilimi analiz yöntemini mekan kurgusunu oluşturan mekansal ilişkilerin değişimini analiz etmek amacıyla kullanmaktadır. 
Mekansal kurgunun analizi ile mekansal komşuluk kavramına odaklanan çalışmada sınanmaya çalışılacak hipotezler şu şekilde sıralanabilir:

1) Mekan ve mekansal ilişkiler yaşamın karşılığıdır. Yaşamın değiştiği farklı dönemlere ait konut mekanlarında farklı mekansal kurgular oluşur.

2) Mekan kurgusunda ilişkiler değişirse mekanın karakteri değişmiş olur.

3) Mekanın karakteri, kullanımı ve anlamı ilişkili olduğu mekanlarla karakterize edilir.

Çalışmanın yukarıda belirtilen hipotezlerinin denenmesi amaciyla geçiş diyagramı modellemeleri ve geçiş kuramsal analizleri yapılmıştır. Bu kapsamda;

a) Hipotez 1'in denenmesi amaciyla konutların geçiş diyagramları analiz edilerek her bir dönem için geçiş diyagramlarının değişimi tespit edilmeye,

b) Hipotez 2'nin denenmesi için her bir dönem konutunda merkez mekanın geçiş diyagramı çözümlemeleriyle ilişki olduğu mekanlar, derinlik ve entegrasyon analizleriyle dizilim içindeki yerleri ve buna dayanarak değişen mekan karakteri saptanmaya,

c) Hipotez 3'ün denenmesi için Hipotez 2'nin denenmesi sırasında elde edilen bulguların yanı sıra, dönemler arasında geçiş analizlerinde değişen mekansal ilişkilerin saptanmasıyla edinilen bulgular yardımıyla değişimin mekan karakterini nasıl etkilediği bulunmaya çalışılmıştır.

Geçiş diyagramlarında konut içi mekanın sonlanarak konut dışı mekana geçilen ilk nokta kök mekan olarak alınmıştır. Bu mekan geçiş modellerinde merdiven holü, sokak ve giriş verandası olarak tespit edilmiştir. Çalışma kapsamında yapılacak olan analizler ve hesaplamalar için UCL Space Syntax Lab. tarafindan geliştirilen Depthmap X paket programı kullanılmış, derinlik ve entegrasyon analizlerinde Radius ( $n$ ) olarak kabul edilmiştir.

\subsection{Bulgular}

\subsubsection{0-1930 Dönemi Adana Konutunun Genel Karakteri ve Analiz Bulguları}

1920'lerde geleneksel tarihi dokuda görülen tipik konut uygulamaları, geleneksel karakteri devam ettiren, zemin katı geçiş ve servis alanlarına ayrılmış 2-3 katlı konutlardır. Bu konutların ana yaşam katında orta sofa anlayışının tekrarı bir mekan ve ona açılan odalar yer alır. 1930'larla birlikte Jansen Planının önerdiği kentin yeni yerleşim alanlarında ise geleneksel etkilerden uzak, işlevin biçimlendirdiği rasyonel ve yalın geometrik formların kullanıldığı konut uygulamaları gerçekleştirilmiştir. $\mathrm{Bu}$ dönemde genelde yaşama mekanlarının zemin katta, yatak odalarının ise üst katta yer aldığı örneklere, tek aile kullanımına yönelik tasarlanmış müstakil konutlara ve bunlarin yanı sira tek konut görünümünde olup iki ayrı daireli kat evi olarak çözümlenmiş örneklere de rastlanmaktadır.

Birinci dönem konutların geçiş kuramsal analizleri sonucunda merkez mekanın sofa mekanı olduğu, 4-5 adım derinlikli geçiş modellerinde merkez mekanın kök mekandan 2 veya 3 adım derinde olduğu tespit edilmiştir. Modern şemada gelenekselden farklı olarak merkez mekana alternatif ikinci bir merkezin oluştuğu görülmüştür. Geçiş modelleri geleneksel plan şemasına sahip 76 Numaralı Ev ve Hayriye Hanım Evi'nde derin dallı ağaç, modern plan şemasına sahip Şevket Bey Evi'nde ise sığ halkalı çalı formundadır (Şekil 5).

Merkez mekan ve ona bağlanan diğer mekanlar arasında geleneksel şemalarda halkalı geçişler bulunmazken modern şemada bulunur. Geleneksel şemanın bu ilişki düzeni mekanların içe dönük ve merkez mekanın kontrolündeki kullanımını ve odaların daha bireysel, merkez mekanın ise daha genel kullanımda olduğunu işaret eder. Modern şemada ise halkalı geçişlerin servis mekanları hariç tüm yaşama ve yatma mekanları arasında olduğu görülür. $\mathrm{Bu}$ bulgu henüz mekan kullanımında 

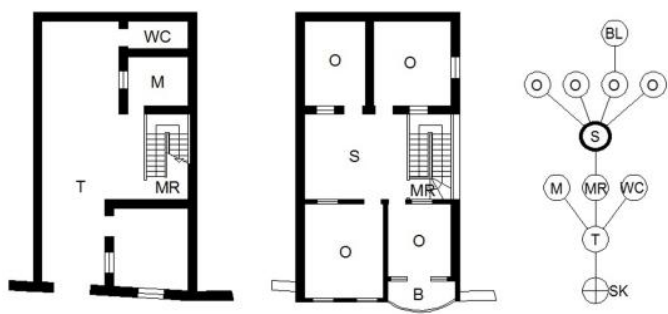

ZEMIN KAT PLANI UST KAT PLANI 76 ENVANTER NOLU EV 76 Envanter Nolu Ev, 1920 'ler [12]

Entegrasyon Dizilimi (ort. değer: 0,902) $\mathbf{S}>\mathbf{M R}>\mathbf{T}>\mathrm{O}>\mathrm{O}=\mathrm{O}=\mathrm{O}>\mathrm{SK}=\mathrm{M}=\mathrm{WC}>\mathrm{BL}$

Ort. Derinlik Dizilimi (ort. değer: 2,655) $\mathbf{S}<\mathbf{M R}<\mathbf{T}<\mathbf{O}<\mathrm{O}=\mathrm{O}=\mathrm{O}<\mathrm{SK}=\mathrm{M}=\mathrm{WC}<\mathrm{BL}$

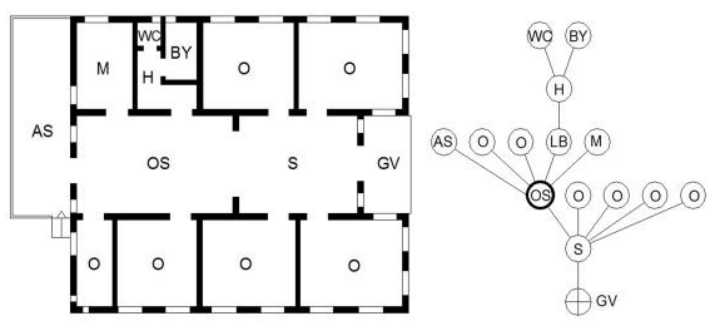

$$
\text { KAT PLANI HAYRIYE HANIM EVI }
$$

Hayriye Hanım Evi, 1930 'lar [13]

Entegrasyon Dizilimi (ort. değer: 1,254)

$\mathbf{O S}>\mathbf{S}>\mathbf{H}>\mathrm{M}=\mathrm{O}=\mathrm{O}=\mathrm{AS}>\mathrm{GV}=\mathrm{O}=\mathrm{O}=\mathrm{O}=\mathrm{O}>\mathrm{WC}=\mathrm{BY}$

Ort. Derinlik Dizilimi (ort. değer: 2,462)

$\mathbf{O S}<\mathbf{S}<\mathbf{H}<\mathbf{M}=\mathbf{O}=\mathbf{O}=\mathbf{A S}<\mathrm{GV}=\mathrm{O}=\mathrm{O}=\mathrm{O}=\mathrm{O}<\mathrm{WC}=\mathrm{BY}$

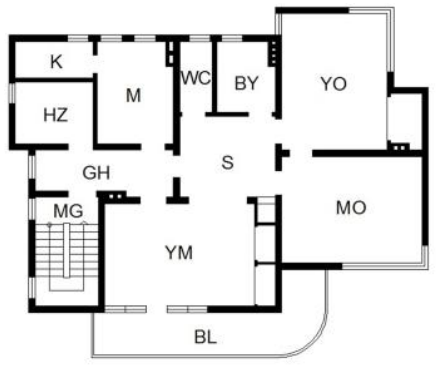

KAT PLANI

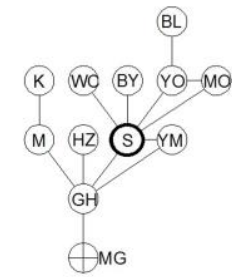

Dişçi ȘEVKET BEY EVI

Şevket Bey Evi, 1933, Semih Rüstem [14]

Entegrasyon Dizilimi (ort. değer: 1,297)

$\mathbf{S}=\mathbf{G H}>\mathbf{Y M}>\mathrm{M}>\mathrm{YO}=\mathrm{MO}>\mathrm{MH}=\mathrm{HZ}=\mathrm{BY}=\mathrm{WC}>\mathrm{BL}>\mathrm{K}$

Ort. Derinlik Dizilimi (ort. değer: 2,303)

$\mathbf{S}=\mathbf{G H}<\mathbf{Y M}<\mathbf{M}<\mathrm{YO}=\mathrm{MO}<\mathrm{MH}=\mathrm{HZ}=\mathrm{BY}=\mathrm{WC}<\mathrm{BL}<\mathrm{K}$

*dizilimlerde koyu ifadeler ortalama değerin altında ve üstünde kalan mekanlarl ifade eder.

Şekil 5. 1920-1930 dönemi Adana konutunun mekan dizilimi analizi işlevsel ayrımın tam olarak yapılamadığını göstermektedir. $\mathrm{Bu}$ dönemde merkeze en yakın mekanlar sirkülasyonun sağlandığı taşıyıcı mekanlarken, merkezden uzak mekanlar ise odalar, mutfak, wc, banyo ve balkondur.

\subsubsection{0-1950 Dönemi Adana Konutunun Genel Karakteri ve Analiz Bulguları}

$\mathrm{Bu}$ dönemde kentin yeni gelişen bölgelerinde uygulanan apartman plan şemalarında geleneksel karakterden uzaklaşma çabası belirgindir. Apartmanların öncü örneklerinde değişen yaşam biçimi ve konut kültürünün etkisiyle mekan kurgusunda yenilikçi denemeler ortaya çıkmakla beraber bunların büyük kısmı beklentileri karşılamaktan uzak çözümlerdir. Plan şemalarında bir yandan orta sofa benzeri yaşama mekanı çözümlemeleri ile gelenekselin devamı anlayış sürerken, bir yandan da işlevsel gruplamaların tanımlandığı modern tasarım anlayışının yaygınlaştı̆̆ gözlenmektedir.

İkinci dönem geçiş kuramsal analizlerine göre günlük odanın konutun merkez mekanı olduğu belirlenmiştir. Geçiş modellerinde koyu renkli daire ile işaretlenen merkez mekanın kök mekandan daima 2 basamak uzakta yer aldığ tespit edilmiştir.

Halkalı geçiş ilişkisinin daha çok görüldüğü bu dönem konutlarında modeller 5 adım derinlikli halkalı ağaç formdadır. Tüm modellerde merkez mekan halka üzerinde ve rotaların değişim noktasında bulunur. Bununla beraber şemada yeni işlevsel grupların oluşmasıyla ikincil merkezlerin belirdiği tespit edilmiştir. $\mathrm{Bu}$ gruplamaların mutfak, wc ve hol ilişkisiyle servis mekanları arasında, yatak odaları, banyo, gece holü ilişkisiyle uyuma, dinlenme-mahremiyet mekanları arasinda oluştuğu görülmüştür (Şekil 6). Bunun sonucunda gece holü ve servis mekanlarının bağlandığı holler gruplanan mekanlara ulaşımı ve geçişi sağlayan görevleri nedeniyle ikincil merkezleri oluşturmuştur.

Merkez mekanın diyagram üzerindeki durumu incelendiğinde ise merkez mekanın simetrisinde daima bir başka mekan olduğu görülür. Geçiş 
modellerine göre simetride, merkez mekanla aynı derinlik değerine sahip olarak misafir odası ve hol bulunmaktadır.

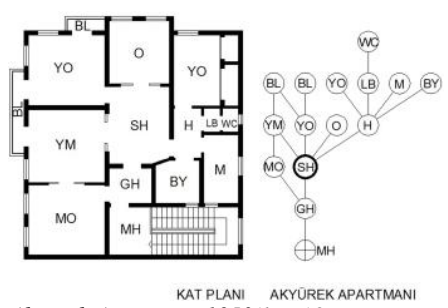

Akyürek Apartmani, 1950 'ler [13]

Entegrasyon Dizilimi (ort. değer: 1,093)

$\mathbf{S H}>\mathbf{H}>\mathbf{G H}=\mathbf{Y O}=\mathbf{Y M}>\mathrm{O}>\mathrm{LB}>\mathrm{YO}=\mathrm{M}=\mathrm{BY}>\mathrm{MO}=\mathrm{BL}>\mathrm{MH}=\mathrm{BL}>\mathrm{WC}$

Ort. Derinlik Dizilimi (ort. değer: 2,724)

$\mathbf{S H}<\mathbf{H}<\mathbf{G H}=\mathbf{Y O}=\mathbf{Y M}<\mathbf{O}<\mathbf{L B}<\mathrm{YO}=\mathrm{M}=\mathrm{BY}<\mathrm{MO}=\mathrm{BL}<\mathrm{MH}=\mathrm{BL}<\mathrm{WC}$

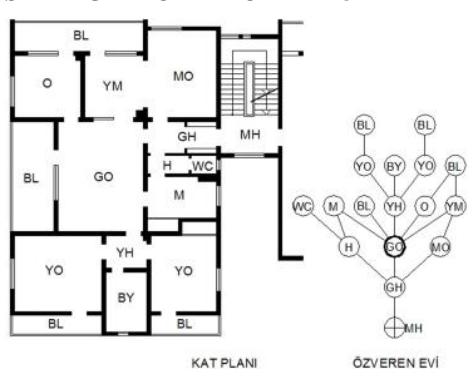

Özveren Evi,1950'ler [13]

Entegrasyon Dizilimi (ort. değer: 1,068)

$\mathbf{G O}>\mathbf{Y H}>\mathbf{G H}>\mathbf{Y M}=\mathbf{M}>\mathbf{O}>\mathrm{BL}>\mathrm{MO}=\mathrm{H}=\mathrm{YO}=\mathrm{YO}>\mathrm{BY}>\mathrm{MH}>\mathrm{B}$ $\mathrm{L}>\mathrm{BL}=\mathrm{BL}=\mathrm{WC}$

Ort. Derinlik Dizilimi (ort. de ğer: 2,911)

$\mathbf{G O}<\mathbf{Y H}<\mathbf{G H}<\mathbf{Y M}=\mathbf{M}<\mathbf{O}<\mathbf{B L}<\mathrm{MO}=\mathrm{H}=\mathrm{YO}=\mathrm{YO}<\mathrm{BY}<\mathrm{MH}<\mathrm{B}$ $\mathrm{L}<\mathrm{BL}=\mathrm{BL}=\mathrm{WC}$

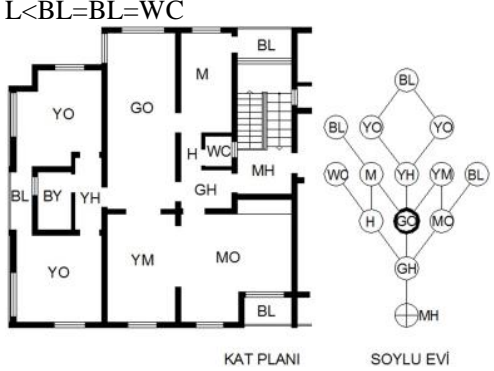

Soylu Evi,1958, Melahat Öngen [13]

Entegrasyon Dizilimi (ort. değer: 0.971)

$\mathbf{G O}>\mathbf{G H}>\mathbf{Y H}>\mathbf{M}>\mathbf{Y M}>\mathbf{H}>\mathrm{MO}>\mathrm{MH}=\mathrm{YO}=\mathrm{YO}>\mathrm{BY}>\mathrm{BL}>\mathrm{WC}$ $>\mathrm{BL}>\mathrm{BL}$

Ort. Derinlik Dizilimi (ort. değer: 2,914)

$\mathbf{G O}<\mathbf{G H}<\mathbf{Y H}<\mathbf{M}<\mathbf{Y M}<\mathbf{H}<\mathbf{M O}<\mathrm{MH}=\mathrm{YO}=\mathrm{YO}<\mathrm{BY}<\mathrm{BL}<\mathrm{WC}$ $<\mathrm{BL}<\mathrm{BL}$

* dizilimlerde koyu ifadeler ortalama değerin altında ve üstünde kalan mekanlart ifade eder.

Şekil 6. 1940-1950 dönemi Adana konutunun mekan dizilimi analizi
Bu bulgunun mekansal ilişkiler bakımından önemli bir noktayı işaret ettiği düşünülmektedir. Bu dönem plan şemaları gelenekselden modern geçiş çabasını içermekte ve merkez mekan hem geçiş hem de ailenin günlük yaşam mekanı olarak tanımlanmaktadır. Öte yandan modern yaşama ait salon ve yemek odası gibi mekanları kurguya dahil etme çabası konfigürasyonda simetrinin oluşmasına neden olmuştur. Halkalı geçişlerde simetrinin "birbirleriyle eşit kontrollü ilişki düzeni" olarak değerlendirilmesi bu bulgunun geçerliliğini desteklediği düşünülmektedir. $\mathrm{Bu}$ durumda mevcut geçiş modellerinde simetriyi oluşturan mekanların merkez mekana işlevsel olarak alternatif olduğu söylenebilir. Oluşan dizimsel simetride misafir odası hane halkı dışındaki kullanıcılar için hane halkının yaşama mekanı olan merkez mekana işlevsel olarak alternatif bir mekan haline gelmektedir.

Dizimsel uzaklıklar bakımından ise merkeze en yakın mekanların yatak holü, giriş holü, yemek odası ve mutfak, en uzak mekanların ise misafir odas1, yatak odası, wc, banyo ve balkonlar olduğu belirlenmiştir.

\subsubsection{0-1970 Dönemi Adana Konutunun Genel Karakteri ve Analiz Bulguları}

1960-1970 yılları arasında kalan dönemde müstakil konut uygulamaları önemli ölçüde azalmış, buna karşın 3-4 katlı aile apartmanları ile 4-8 katlı kira apartmanları yaygınlaşarak devam etmiştir. Apartman plan şemasının olabildiğince netleştiği bu dönemde gece ve gündüz kullanımı belirgin bir şekilde ayrılmış, mekanda kullanıcı mahremiyetinin sağlanmasına özen gösterilmiştir.

Üçüncü dönem konut örneklerinde geçiş modeli 45 derinlikli, sığ halkalı çalı ve halkalı ağaç formundadır. Merkez mekan bu dönemde kök mekandan 1 basamak derinlik uzaktadır. Plan şemalarının işlevsel olarak belirgin biçimde netleştiği bu dönemde mekanlar çoklu fonksiyonlu karakterinden sıyrılmaya başlamıştır. Bu değişim mekan kurgusunda ve dolayısıyla geçiş modellerinde açıkça gözlenmektedir. Geçiş diyagramları incelendiğinde merkez mekanın 
bulunduğu derinlikte simetrisinde yer alan başka bir mekanın bulunmadığı görülür (Şekil 7).

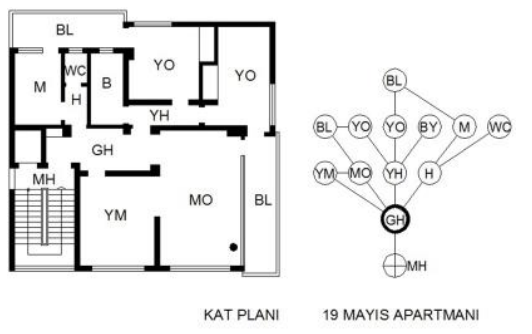

19 Mayls Apartmanı,1960'lar [13]

Entegrasyon Dizilimi (ort. değer: 1,160)

$\mathbf{G H}>\mathbf{Y H}>\mathbf{H}>\mathbf{M O}>\mathbf{Y M}=\mathbf{Y O}>\mathrm{YO}>\mathbf{M H}>\mathbf{M}=\mathrm{BL}>\mathrm{BY}>\mathrm{BL}>\mathrm{WC}$ Ort. Derinlik Dizilimi (ort. değer: 2,436)

$\mathbf{G H}<\mathbf{Y H}<\mathbf{H}<\mathbf{M O}<\mathrm{YM}=\mathrm{YO}<\mathrm{YO}<\mathrm{MH}<\mathrm{M}=\mathrm{BL}<\mathrm{BY}<\mathrm{BL}<\mathrm{WC}$

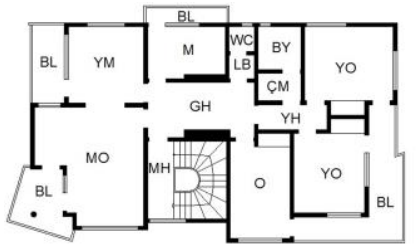

KAT PLANI

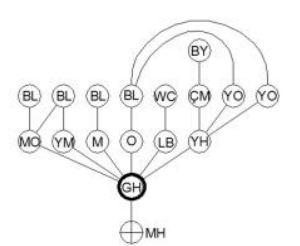

NACAR APARTMAN
Nacar Apartmanı, 1964 [13]

Entegrasyon Dizilimi (ort. de ğer: 1,220)

$\mathbf{G H}>\mathbf{Y H}>\mathbf{M O}>\mathbf{Y M}=\mathbf{O}>\mathrm{M}=\mathrm{LB}>\mathrm{MH}>\mathrm{YO}=\mathrm{YO}>\mathrm{C} M=\mathrm{BL}>\mathrm{BL}>\mathrm{BL}>$ $\mathrm{BL}=\mathrm{WC}>\mathrm{BY}$

Ort. Derinlik Dizilimi (ort. de ğer: 2,699)

$\mathbf{G H}<\mathbf{Y H}<\mathbf{M O}<\mathbf{Y M}=\mathbf{O}<\mathbf{M}=\mathbf{L B}<\mathbf{M H}<\mathrm{Y} O=\mathrm{YO}<\mathrm{CM}=\mathrm{BL}<\mathrm{BL}<\mathrm{BL}$ $<\mathrm{BL}=\mathrm{WC}<\mathrm{BY}$

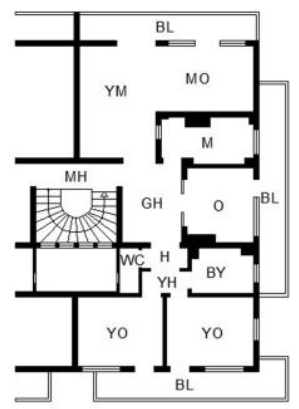

KAT PLANI

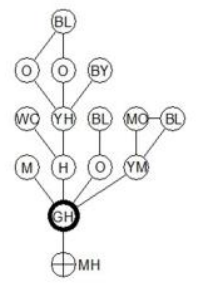

BIRLIK APARTMAN
Birlik Apartmanı, 1970 'ler [13]

Entegrasyon Dizilimi (ort. değer: 0,913)

$\mathbf{G H}>\mathbf{H}>\mathbf{Y H}>\mathbf{Y M}>\mathbf{O}>\mathrm{MH}=\mathrm{M}>\mathrm{WC}>\mathrm{YO}=\mathrm{Y} \mathrm{O}>\mathrm{BY}>\mathrm{MO}=\mathrm{BL}>\mathrm{BL}>\mathrm{BL}$ Ort. Derinlik Dizilimi (ort. değer: 3,029)

$\mathbf{G H}<\mathbf{H}<\mathbf{Y H}<\mathbf{Y M}<\mathbf{O}<\mathbf{M H}=\mathbf{M}<\mathbf{W C}<\mathrm{YO}=\mathrm{YO}<\mathrm{BY}<\mathrm{MO}=\mathrm{BL}<\mathrm{BL}<\mathrm{BL}$

*dizilimlerde koyu ifadeler ortalama değerin altında ve üstünde kalan mekanlart ifade eder.

Şekil 7. 1960-1970 dönemi Adana konutunun mekan dizilimi analizi
Böylelikle merkez mekan sadece sirkülasyon elemanı olurken, önceki dönemlerde merkez mekanın yüklendiği ailenin günlük oturma alanı olma işlevi ise merkez mekana açılan bir odayla sağlanmıştır. $\mathrm{Bu}$ tespitler mekansal ilişkilerin değişiminin ve bu değişimin mekanın kullanımına yansımasının belirgin işaretleri olarak değerlendirilebilir.

Bu dönemde de halkalı geçişler kurguda yer alır ve bu geçişler giriş holü, misafir odası ve yatak holü arasında bulunur. Ancak bu dönemde halkaların kurgudaki rolünün önceki dönemlere göre değiştiği görülmektedir. Halkalı geçişlerin varlığı halka üzerinde yer alan mekanın diğerleriyle eşit kontrollü ilişkisi olarak açıklansa da mekanlar arasında gerek duyulan işlevsel ilişkiyi sağlama çabasını işaret etmektedir. Bu dönemde merkeze en yakın mekanlar holler, misafir odası, yemek odas1 ve oda, merkezden en uzak mekanlar yatak odaları, wc, banyo ve balkonlardır.

\section{SONUC}

Dizilim analizi ve geçiş diyagramı modelleri dönemlerin birbiri içinde ortak ve birbirlerine göre değişen özelliklerini tespit etmeye yardımcı olmuştur. Sosyal ve kültürel farklılıkların oluştuğu dönemler arasında açı bir şekilde mekan kurgusunun da farklılaştı̆g 1 tespit edilmiştir. $\mathrm{Bu}$ tespitin çalışmanın ilk hipotezini doğruladığı düşünülmektedir. Her dönemin kendine özgü mekansal ilişkiler geliştirdiği ancak bunu yaparken bir önceki dönemden izler taşıdığı da ayrıca bulunmuştur. Bu bulgu konutun kültürel bir olgu olması ve kültürün öğrenilerek aktarılan niteliğiyle açıklanabilir. Farklılaşan dönemlerde her seferinde yeniden keşfedilen bir konut şeması yerine bir önceki şema üzerinden geliştirilerek elde edilmiş bir şemanın varlığından söz edilebilir.

Ele alınan dönem örneklerinde şemanın evrilerek değişimi geçiş diyagramlarından kolaylıkla izlenebilmektedir. Gelenekselden modern tasarım anlayışına doğru gelişen süreçte geçiş diyagramları derin dallı ağaç formundan sığ halkalı çalı formuna doğru değişime uğramıştır. Konutun mekansal ilişki şemasında görülen bu değişim yeni mekansal 
ilişkilerin altını çizerken, buna paralel olarak yeni mekan kullanımları ve işlevsel alan tanımlarının oluştuğu tespit edilmiştir. $\mathrm{Bu}$ bağlamda birinci dönemde merkez mekanla odaların doğrudan ilişkisinin ikinci dönemde kısmen daha dolaylı hale geldiği, üçüncü dönemde ise tamamen ayrıldığı görülmüştür. Değişim sürecinin ilk dönemlerinde merkez mekan çok fonksiyonlu olarak hane halkına hizmet ederken, sonraki dönemlerde odaların çok fonksiyonlu kullanımı kısıtlanmış, hane halkı dışından kullanıcılar için misafir odas1, yemek salonu gibi yeni mekan tanımları ve ilişkileri geliştirilmiştir. Bunun sonucunda merkez mekan kök mekana göre daha derinden daha sığ bir konuma geçmiştir. Merkez mekanın geçiş modeli üzerinde yerinin değişimi çoklu fonksiyondan tekli fonksiyona geçişinin göstergesi olarak düşünülebilir.

İkinci dönemde çokça görülen halkalı geçişler ve rota değişimi önerilen yeni mekansal ilişkilerin ve kullanımların sağlanabilmesi için bir araç haline gelmiştir. Birinci dönemden ikinci döneme geçerken halkalar yeni mekansal ilişkilerin mevcut şemaya dahil edilmesini sağlama görevini üstelenmiştir. $\mathrm{Bu}$ anlamda çok fonksiyonlu sofa mekanından, günlük yaşama ve yemek odası olarak ayrılmış yeni mekansal kullanımlar şemaya ve yaşantıya adapte edilirken halkalı geçişler yardımıyla eski mekansal ilişkiler terkedilmeyerek varlıklarını sürdürmüşlerdir. İkinci dönemden üçüncü döneme geçilirken ise halkalar daha çok işlevsel ilişkileri sağlamak için kullanılmıştır.

$\mathrm{Bu}$ tespitlere ek olarak mekansal ilişkilerin değişimi konutta gece ve gündüz kullanımının ayrılmasını sağlamış, hollerin oluşmasına ve mekanlar arasında kademeli geçişlere neden olmuş, işlevsel gruplamaların belirginleştiği görülmüştür. Analiz edilen son dönemde bu değişim tekil merkezin yanında ikincil merkezin oluşmasıyla sonuçlanmıştır. Bu ikincil merkez özel kullanım alanlarını içeren, mahremiyet seviyesinin yüksek olduğu mekanları kontrol etmektedir. Elde edilen bu sonuçlarla çalışmanın ikinci ve üçüncü hipotezlerinin doğrulandığı düşünülmektedir.

Plan şemasında ilişkili yakınlık olarak tanımlanan mekansal komşuluğun geometrik biçimlenişte sınırdaş olmanın ötesinde anlamlar taşıdığı, mekansal komşuluk ilişkisinin değişmesiyle mekanın işlevsel karakterinin değiştiği tespit edilmiştir. Ulaşılan bu sonuç merkez mekanın üç dönemde farklı mekansal ilişkilere sahip olmasıyla açıklanabilir. Birinci dönemde sofa olan merkez mekan, ikinci dönemde günlük odaya, üçüncü dönemde ise giriş holüne dönüşmüştür. Merkez mekana ait ilişsilerin değişimi mekanın işlevsel karakterini değiştirirken mekanın anlamsal olarak da farklılaşmasını sağlamıştır. Bu tespitler 1şığında mekan kurgusu içinde her bir dönemin kendi içinde benzer mekansal komşuluk ilişkisine sahip olduğunu, dönem içinde farklı geometrik biçimlenmeler görülse de mekan kurgusunun benzerlikler taşıdığını ayrıca söylemek mümkündür.

Çalışma aracılığıyla mekansal ilişkiler ve mekan kurgusu konularına, çalışmada tanımlanan "mekansal komşuluk" kavramıyla farklı bir bakış geliştirilmek istenmiştir. Bu kapsamda Adana'da 1920-1970 yılları arasına yayılan üç ayrı dönemde inşa edilmiş konut şemaları yardımıyla mekansal komşuluk kavramı tartışılmaya çalışılmıştır. Ulaşılan sonuçlar değişen geometrilerde benzer mekansal komşuluk ilişkilerinin varlığını ve mekansal ilişkilerin değişmesiyle mekanın işlevsel ve anlamsal değerinin değiştiğini ortaya koymaktadır.

\section{TEŞEKKÜR}

Bu çalışma Çukurova Üniversitesi BAP Birimi tarafindan FBA-2016-7534 proje kodu ile desteklenmiştir.

\section{KAYNAKLAR}

1. Markus T.A., 1993. Buildings as Social Objects, Companion to Contemporary Architectural Thought, Farmer B., Louw H. (eds.), Routledge, London, UK, p.15-20.

2. Hillier B., Hanson J., Graham H., 1987. Ideas are in Things: an Application of the Space Syntax Method to Discovering House Genotypes, Environment and Planning B: Planning and Design, 14 (4), 363-385. 
3. Ireland T., 2015. The spatiality of Being, Biosemiotics, 8, 381-401.

4. Peponis J., 1997. Geometries of Architectural

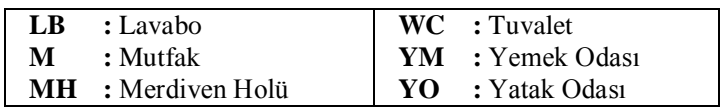
Description, First International Space Syntax Symposium, Vol. 2, 34.1-34.8, 16-18 Nisan, London, UK.

5. Hillier B., Hanson J., 1984. The Social Logic of Space, Cambridge University Press, Cambridge, UK.

6. Hillier B., 2014. Space Syntax as a Method and as a Theory, $21^{\text {st }}$ International Seminar on Urban Form - ISUF2014, Porto, Portugal, 3-6 Temmuz, http://isuf2014.fe.up.pt/Hillier.pdf, Erişim tarihi Kasım 21, 2016.

7. Hillier B., 2007. Space is the Machine, Space Syntax, UCL, London, UK.

8. Peponis J., Wineman J., 2002. Spatial Structure of Environment and Behavior, Handbook of Environmental Psychology, Bechtel R.B., Churchman A. (eds.), John Wiley \& Sons, NY, ABD, 271-291.

9. Karaman F., Erman O., 2014. From Traditional to Modern: Changes in the Spatial Structure of Single Family Houses in Turkey, International Journal of Academic Research, 6(5), 64-74.

10. Marcus C.C., 1995. House as a Mirror of Self, Conari Press, Berkeley, CA, ABD.

11. Erman O., Karaman F., Saban D., Durukan İ., 2007. Adana'da 1930'lardan Günümüze, Sosyal, Kültürel ve Ekonomik Değişimler Bağlamında Konut Mimarisinin Gelişimi, Çukurova Üniversitesi Mühendislik Mimarlık Fakültesi Dergisi, 22(2), 235-247.

12. Adana Kültür ve Tabiat Varlıklarını Koruma Bölge Kurulu, Adana İli, 76 Envanter Numaralı Taşınmaz Kültür Varlığı Tescil Fişi.

13. Onur ERMAN Arşivi.

14. Semih Rüstem, 1933. Şevket Bey Evi, Arkitekt, 1933-04(28), 99-102.

\section{KISALTMALAR}

\begin{tabular}{|ll|ll|}
\hline AS & : Açık Sofa & MO & : Misafir Odası \\
BL & : Balkon & MR & : Merdiven \\
BY & : Banyo & O & : Oda \\
ÇM & : Çamaşırlık & OS & : Orta Sofa \\
GH & : Giriş Holü & S & : Sofa \\
GO & : Günlük Oda & SH & : Sofa Hol \\
GV & : Giriş Verandası & SK & : Sokak \\
H & : Hol & T & : Taşlık \\
\hline
\end{tabular}

